\title{
ЗНАЧЕННЯ ЕЛЕКТРОКАРДІОГРАФІЇ В ДІАГНОСТИЦ ТРОМБОЕМБОЛІЇ ЛЕГЕНЕВОЇ АРТЕРІЇ НА ПЕРВИННОМУ РІВНІ МЕДИЧНОї ДОПОМОГИ
}

\author{
С. О. Шейко
}

\author{
Д3 “Дніпропетровськамедична академія МОЗ України”
}

\section{VALUE OF ELECTROCARDIOGRAPHY IN DIAGNOSTICS OF THROMBEMBOLISM OF PULMONARY ARTERY AT PRIMARY STAGE OF HEALTH CARE}

\author{
S. O. Sheiko \\ SI "Dnipropetrovsk Medical Academy of MPH of Ukraine"
}

\begin{abstract}
На сьогодні тромбоемболія легеневої артерії (ТЕЛА) залишається актуальною проблемою кардіології. Невиправдано мало уваги приділяється такому класичному методу обстеження, як електрокардіографія (ЕКГ), який при певних обставинах є основним методом діагностики ТЕЛА.

Акцент навчання лікарів необхідно змістити на поглиблення клінічних знань та практичних навичок інтерпретації електрокардіографічних змін у хворих з ТЕЛА. Це сприятиме своєчасній діагностиці та підвищенню ефективності лікування даної категорії хворих.
\end{abstract}

Today thrombembolism of pulmonary artery (TEPA) remains topical problem of cardiology. Unreasonably little attention is paid to such a classic method of examination as electrocardiography (ECG), which under certain circumstances is the basic method of TEPA diagnostics.

While training physicians it is necessary to shift an accent on deepening clinical knowledge and practical skills of interpreting electrocardiographic changes in patients with TEPA. This will contribute to timely diagnostics and rising of efficiency of treatment of this category of patients.

Вступ. В клінічну практику все ширше впроваджуються такі дороговартісні методи дослідження серцево-судинної системи, як ультразвукова доплероехокардіографія, комп'ютерна рентгенотомографія, ангіокардіографія, катетеризація порожнин серця і судин, парамагнітоядерний резонанс, електрографія провідникової системи, реєстрація пізніх потенціалів серця, кардіотопографія активних зон тощо [1-4]. Не викликає сумнівів, що можливості цих методів нерідко перебільшують їх роль і значення для діагностики певних захворювань. Проте кожен з них повинен мати свою нішу в діагностичному ланцюгу. Рaзом 3 тим, невиправдано мало уваги приділяється такому класичному методу обстеження, як електрокардіографія, який при певних обставинах є основним методом діагностики.

На сьогодні, коли патологія серцево-судинної системи займає провідне місце, електрокардіографія (ЕКГ) є невід'ємною складовою кардіологічного обстеження $[3,4]$. Але досвід викладання показує, що

(ㄷ С. О. Шейко в інтерпретації ЕКГ лікарі первинної ланки зустрічають певні труднощі. Тому актуальним є оволодіння лікарем нового покоління методологією аналізу ЕКГ для з'ясування основних ЕКГ-синдромів у клінічному аспекті.

Основна частина. Особливу увагу необхідно приділяти поглибленню знань лікарів з невідкладної діагностики і клінічної інтерпретації ЕКГ. Актуальною проблемою невідкладних станів $\epsilon$ тромбоемболія легеневої артерії (ТЕЛА) - одне з поширеніших ускладнень багатьох захворювань, що являють загрозу для життя людини. Тому швидка та коректна діагностика ТЕЛА на первинному рівні медичної допомоги $€$ наріжним каменем ведення хворих із цією патологією, оскільки чим раніше встановлений діагноз, тим більш ефективним може виявитись лікування. Таким чином, напервинному рівні діагностики окрім клінічної інтерпретації даного синдрому важливе значення має електрокардіографічна діагностика.

Відомо, що серед пацієнтів терапевтичного профілю найчастіше ТЕЛА виникає при інсульті, інфаркті міокарда (IM), гострих терапевтичних захворюван- 
нях, а такожу людей похилого віку. За даними Фремінгемського дослідження, смертність від ТЕЛА складає 15,6 \% усієї госпітальної смертності (при хірургічних захворюваннях - $18 \%$, терапевтичних - $82 \%$ випадків). ТЕЛА - розповсюджене захворювання, яке в США зустрічається у 200 тис. людей, помирає від нього щорічно 10-15 \% пацієнтів (якщо такі хворі не лікуються, то смертність складає 30 \%). До факторів підвищеного ризику належать: вік $>40$ років,

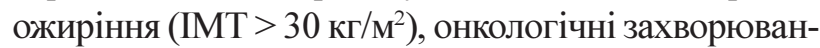
ня, варикоз вен, наявність тромбозів та емболій в анамнезі, застосування естрогенів, порушення ритму серця, особливо фібриляція передсердь, серцева недостатність, легенева недостатність, запальні захворювання кишок, нефротичний синдром, мієлопроліферативний синдром, пароксизмальна нічна гемоглобінурія, куріння, наявність катетера в центральній вені, ідіопатична та набута тромбофілія. Закупорка легеневої артерії може здійснюватись тромбом, краплями жиру кісткового мозку, повітрям, паразитами (аскаридами). Найчастіше ТЕЛА зустрічається при таких захворюваннях:

- флебітах і тромбофлебітах нижніх (рідше верхніх) кінцівок, таза (75\%);

- новоутвореннях різних органів;

- серцево-судинних захворюваннях з вираженою кардіомегалією, великими порожнинами лівого і правого шлуночків (мітральний стеноз, ішемічна хвороба серця (IXC), IM, дилатаційна кардіоміопатія, дифузні міокардити, інфекційний ендокардит, фібриляція передсердь (ФП), хронічна серцева недостатність тощо);

- парадоксальній тромбоемболії із лівого в правий шлуночок при дефекті міжшлуночкової та міжпередсердної перетинки;

- хірургічних операціях, тривалій іммобілізації кінцівок, травмах з пошкодженням вен.

У розвитку ТЕЛА до сьогодні актуальна тріада Вірхова, при якій відбувається сповільнення кровотоку, ураження ендотелію судин і підвищення згортання крові.

Згідно з сучасними уявленнями у розвитку ТЕЛА мають значення такі патогенетичні ланки:

- активація потенціалу (згортання) крові, що супроводжується підвищенням агрегації тромбоцитів, зниженням фібринолізу;

- плазмова ланка - зниження синтезу плазміну, антитромбіну III, ендогенних антикоагулянтів; підвищення активності інгібіторів плазміногена;

- судинна ланка - ураження ендотелію судин, збільшення синтезу вазоконстрикторів (тромбоксану, ендотеліну, норадреналіну, ангіотензину II), змен- шення вазодилатуючої функції судин (синтезу оксиду азоту, простацикліну).

Однак провідним фактором розвитку гемодинамічних розладів при ТЕЛА є механічна обструкція легеневого артеріального русла, що призводить до різкого підвищення тиску в легеневій артерії, перенавантаження правого шлуночка. Збільшення судинного опору та підвищення тиску в легеневій артерії призводить до розвитку гострого легеневого серця та правошлуночкової недостатності.

Клінічні симптоми ТЕЛА неспецифічні, вони спостерігаються і при інших серцево-судинних і легеневих захворюваннях. Головні їх відмінності-раптовий початок, відсутність іншої причини розвитку (пневмонії, інфаркту міокарда, серцевої недостатності та ін.). Слід звертати особливу увагу на той факт, що посилення диспное (задишки) у пацієнтів, які мають супутню патологію серця i/або легенів, може бути єдиним симптомом розвитку ТЕЛА. Відсутність таких симптомів, як задишка, тахіпное, тахікардія, біль у грудній клітці, ставлять під сумнів діагноз ТЕЛА. Клінічні прояви ТЕЛА залежать від початкового стану серцевосудинної і дихальної систем. Перебіг залежить від величини тромбу та ураження легеневих артерій у відсотковому відношенні. Зокрема, при ураженні основного стовбура мають місце раптова задишка, ціаноз, дуже сильний біль за грудиною, втрата свідомості, падіння артеріального тиску. При ТЕЛА крупних гілок характерні інтенсивний біль у грудній клітці, що важко знімається, раптова різка задишка та інтенсивний ціаноз верхньої половини тулуба, порушення ритму за типом надшлуночкової тахікардіï, рефлекторне зниження артеріального тиску. При ураженні дрібних гілок легеневої артерії з'являється “немотивована” задишка, помірний ціаноз, помірний біль у грудній клітці, часто пов'язаний з актом дихання, кашель, що нерідко супроводжується кровохарканням, можливі вологі хрипи та шум тертя плеври при аускультації.

Електрокардіографічні зміни (рис. 1) при ТЕЛА можуть бути представлені такими варіантами:

I варіант:

- S-Q ${ }_{\text {III }}$ (синдром McGinn S., White P., 1935) - синдром перевантаження правого шлуночка. Відображає раптовий поворот серця за часовою стрілкою навколо подовжньої осі. Раптова поява зубця $\mathrm{Q}_{\mathrm{III}}$ при одночасному збільшенні амплітуди зубців $\mathrm{R}_{\mathrm{III}}$ i $\mathrm{S}_{\mathrm{I}}$;

- зміщення перехідної зони (глибокий S у відведеннях $\mathrm{V}_{5}-\mathrm{V}_{6}$ у поєднанні з негативним зубцем $\mathrm{T}$ у відведеннях $\mathrm{V}_{1}-\mathrm{V}_{4}$ );

- елевація сегмента ST з негативним зубцем Т у відведеннях III, aVF, $\mathrm{V}_{1}, \mathrm{~V}_{2}$; 
- реципрокнезниження ST у І стандартному відведенні; - поява ЕКГ-ознак неповної або повної блокади правої ніжки пучка Гіса з формуванням комплексу $\mathrm{rSr}, \mathrm{rSR}, \mathrm{RsR}$ та збільшення іï ступеня в міру прогресування процесу;

- високий, загострений “легеневий” зубець Р 3 відхиленням його електричної осі праворуч;

- суправентрикулярна тахікардія або тахісистолічна форма миготіння/тріпотіння передсердь.

II варіант характеризується ЕКГ-змінами тільки в грудних відведеннях:

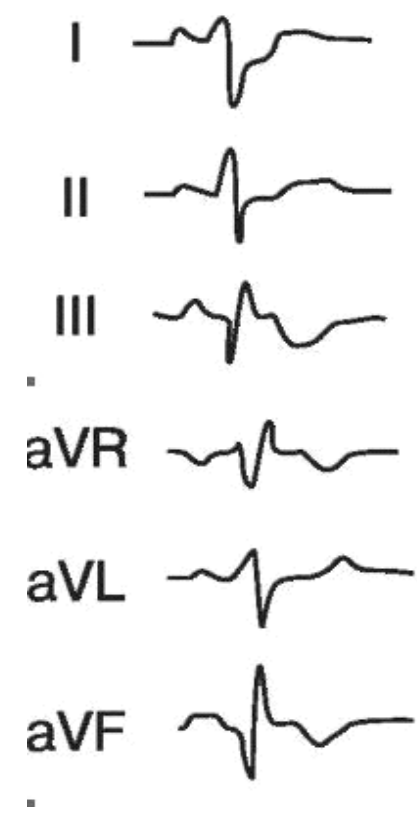

- підвищення ST у відведенні $\mathrm{V}_{2}$;

- зміщення перехідної зони вліво;

- поява в динаміці неглибокого негативного зубця

Т у відведеннях $\mathrm{V}_{2}-{ }_{3}$;

- зворотний розвиток ЕКГ-змін через 1-2 тижні.

III варіант: аритмічний :

- виникає гостре порушення ритму серця у вигляді пароксизмів передсердної тахікардії, пароксизмів миготіння або тріпотіння передсердь при наявності клінічних ознак тромбоемболії легеневої артерії.

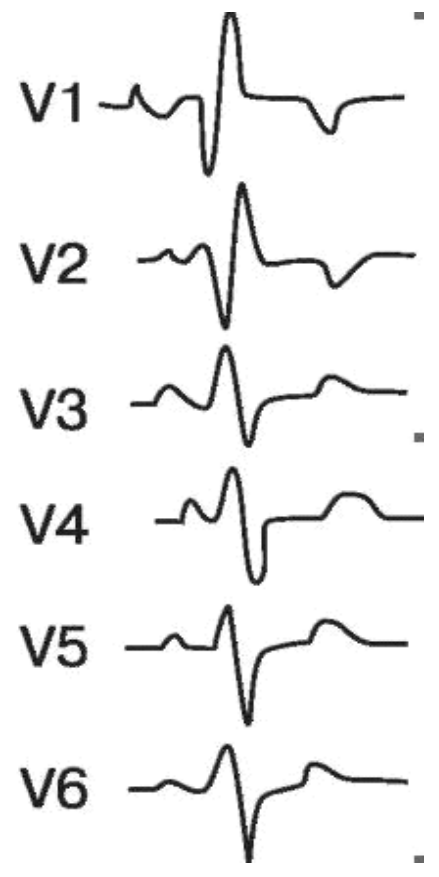

Рис. 1. ЕКГ хворого з ТЕЛА.

Диференційна діагностика ТЕЛА з інфарктом міокарда

\begin{tabular}{|c|c|}
\hline Тромбоемболія легеневої артерії & Задній інфаркт \\
\hline $\mathrm{Q}_{\text {III }}$ глибокий, не широкий $(<0,04$ c) & $\mathrm{Q}_{\text {III }}$ широкий, > 0,03-0,04 c \\
\hline $\mathrm{Q}_{\text {II }}$ не виразний & Виразний $\mathrm{Q}_{\text {II }}$ \\
\hline $\mathrm{ST}_{\mathrm{II}}$ Знижений & Елевація сегмента $\mathrm{ST}_{\text {II }}$ \\
\hline Елевація ST у відведенні $V_{1}$ & Елевація $\mathrm{ST}-\mathrm{T}_{\mathrm{III}}$ \\
\hline Зворотна динаміка ЕКГ-змін протягом 2-3 & Реципрокне зниження ST у відведеннях $V_{1}-V_{3}$ \\
\hline тижнів & $\begin{array}{l}\text { ЕКГ-динаміка відповідно стадії розвитку } \\
\text { інфаркта міокарда }\end{array}$ \\
\hline
\end{tabular}

Висновок. На сьогодні ТЕЛА залишається актуальною проблемою кардіології. Акцент навчання лікарів необхідно змістити на поглиблення клінічних знань та удосконалення практичних навичок інтер- претації електрокардіографічних змін у хворих 3 ТЕЛА. Це сприятиме своєчасній діагностиці та підвищенню ефективності лікування даної категорії хворих. 


\section{ВДОСКОНАЛЕННЯ ВИЩОЇ МЕДИЧНОЇ ОСВІТИ}

\section{Література}

1. Венозний тромбоемболізм: діагностика, лікування, профілактика. Міждисциплінарні клінічні рекомендації / [В. Н. Бойко, I. К. Березницький, І. К. Венгер та ін.]. - Київ, 2013. $-63 \mathrm{c}$.

2. Колиушко Г. И. Тромбоэмболия легочной артерии / Г. И. Колиушко // Ліки України. - 2009. - № 8 (134), - С. 7-10. 3. Тромбоемболія легеневої артерії: сучасні погляди на діагностику та лікування / В. З. Нетяженко, О.М.Плєнова,
О. Гаврилюк [та ін.] // Медицина неотложных состояний. 2013. - №2(49). - С. 4-14.

4.Тромбоемболія легеневої артерії. Уніфікований клінічний протокол екстреної медичної допомоги / М. К. Хобзей, В. Д. Юрченко, С. О. Гур'єв та ін. // Наказ Міністерства охорони здоров’я 15 січня 2014 року № 34.

Отримано 06.05.14 